\title{
ESTADO E CAPITAL FICTÍCIO: \\ O NOVO REGIME FISCAL NO BRASIL
}

João Pedro Vazquez ${ }^{1}$

\section{RESUMO}

Esse trabalho objetiva dissertar sobre a relação entre Estado e capital fictício no Brasil, realizando uma recapitulação histórica da financeirização do capital, processo em que Estado e capital fictício estiveram envolvidos organicamente, e identificando os impactos sobre a América Latina, em geral, e sobre o Brasil, em particular, em que se parte de um exame da dívida pública enquanto forma concreta do capital fictício. Ademais, apoiado numa sumária investigação da conjuntura brasileira recente, realiza-se uma análise do Novo Regime Fiscal desde o prisma da relação Estado-capital fictício.

Palavras-chave: Estado, capital fictício, dívida pública, Novo Regime Fiscal, Brasil. 


\section{Introdução}

Desde as origens do sistema capitalista, Estado e capital estiveram numa aliança, em que o primeiro sustenta o último de diversas formas. Da acumulação primitiva de capital e a repressão para garantia da propriedade privada até os investimentos estatais em infraestrutura e os incentivos à expansão internacional, o Estado capitalista operou a fim de sustentar a reprodução ampliada do capital. Mais recentemente, alterações institucionais realizadas pelos Estados, mediante impulso inicial e controle dos países centrais, causaram mudanças estruturais na configuração do sistema capitalista mundial no que veio a se chamar de financeirização da economia, financeirização do capital, ou mundialização do capital (CHESNAIS, 1996).

A criação do Euromercado de dólares por parte da Inglaterra, a quebra do acordo de Bretton Woods, a desregulamentação e a liberação dos mercados financeiros e o violento aumento da taxa de juros, todas medidas realizadas por parte dos Estados Unidos da América, dão um panorama sobre o papel significativo desempenhado pelo Estado capitalista na transformação dos pilares estruturais do capitalismo no sentido de dar primazia à esfera financeira.

Esse trabalho busca investigar a relação entre Estado e capital fictício, na forma da dívida pública, no Brasil e o papel desempenhado pelo Novo Regime Fiscal nessa relação. Na primeira seção, será exposto a conceituação de capital fictício em Marx e no seio da teoria marxista. Na segunda seção, essa relação será demonstrada dentro do cenário de financeirização do capital, processo que percorreu o último quarto do séc. XX e estabelece alterações estruturais no padrão de acumulação de capital e na configuração institucional do Estado. Em seguida, trataremos de expor sumariamente esse processo na América Latina, na terceira seção, e no Brasil, na quarta seção, dando destaque para o capital fictício na forma da dívida pública. Na quinta parte, será elaborada uma análise sobre o desempenho dos governos do Partido dos Trabalhadores e o panorama brasileiro na conjuntura recente, na perspectiva da crise econômica e do golpe institucional. Por fim, a última seção lança uma reflexão sobre o Novo Regime Fiscal a partir da relação entre Estado e capital fictício.

\section{O conceito de capital fictício em Marx e na teoria marxista:}

Dentro da teoria marxiana, o Estado foi responsável pela consolidação do 
modo de produção capitalista por meio da formação de elementos fundamentais ao seu funcionamento, como por exemplo, a criação da propriedade privada dos meios de produção, por meio da expropriação dos trabalhadores rurais e sua conversão em classe operária das nascentes fábricas, no processo denominado acumulação primitiva de capital. Além disso, o Estado atuou significativamente para a acumulação primitiva de capital por meio da dívida pública. Graças a ela que se desenvolveram as sociedades por ações, os setores comercial e bancário e, sobretudo, o sistema de crédito, patrocinador do processo de acumulação primitiva dos capitais nacionais em expansão colonial (BARBOSA, 2016) (NAKATANI, 2006) (MARX, 2017a).

Esse mesmo sistema de crédito foi responsável, por ação do Estado capitalista, pela subjugação do capital portador de juros (também chamado de capital a juros ou capital usurário) ao capital industrial. O capital portador de juros é o fundamento do sistema de crédito e representa o capital monetário antecipado e destinado a se realizar pelo processo produtivo e voltar às mãos do possuidor na forma de juros, dotando-se da qualidade de capital potencial; e que historicamente é mais antigo (FIORI, 2004) que o capital industrial². No curso histórico de seu desenvolvimento, o capital portador de juros foi subjugado ao funcionamento do capital industrial, empregando, inicialmente, o Estado na forma da redução forçosa da taxa de juros, e, finalmente, pela criação do sistema de crédito. Consolidado esse processo, chega-se ao cenário histórico em que há o predomínio do capital industrial, no qual o polo dominante é o capital produtivo. É importante ressaltar que o capital portador de juros, ainda que se aproprie do mais-valor (na forma de juros) sem produzi-lo, auxilia o capital produtivo na geração de tal mais-valor. CARCANHOLO; NAKATANI, 2015a) (PARANÁ, 2016).

Segundo Carcanholoe Nakatani (2015b), naépoca de Marx, outroelemento que se encontrava subordinado dentro do capital industrial era o que o autor alemão denomina como capital fictício. O capital fictício se origina do desenvolvimento e da generalização do capital portador de juros (SABADINI, 2011; MOLLO, 2011; MARX, 2017b). O capital fictício é a forma de capital cujo valor decorre da especulação de ativos que não possuem correspondência em capital produtivo

2 "O capital industrial, entendido como síntese global e abstrata da circulação de três formas autônomas de capital (o capital a juros, o capital produtivo, o capital comercial), é o mesmo conceito de capital, mas em um nível mais concreto de análise. " (CARCANHOLO; NAKATANI, 2015, p.42) 
real, sob a qual se aplica uma taxa de juros. Os títulos apresentam um movimento de valor relativamente autônomo fazendo crer, isto é, reforçando a ilusão de que constituem num capital real, assim como o capital que representam juridicamente. Isso se deve ao fato dos títulos se tornarem mercadorias cujo valor de mercado é determinado diferentemente do valor nominal (do capital real). É verdadeiro que o valor de mercado flutua em consonância com o volume e a confiabilidade dos rendimentos (ganho real) que conferem os títulos, mas seu valor é principalmente definido pelos ganhos esperados, calculados antecipadamente e, portanto, especulativamente (MARX, 2017b). A perda de relação entre valor de capital real e o valor de mercado dos títulos decorre do fato desses últimos dependerem de expectativas de dividendos capitalizados e de lucros oriundos da venda a preços maiores nos mercados financeiros, não possuindo relação direta com a produção real, isto é, sendo puramente especulativos (MOLLO, 2011).

O capital fictício se forma pelo processo que Marx (2017b) chama de "capitalização", isto é, a propriedade de todo o dinheiro render algum juro, permitindo mesmo o que não é capital a se valorizar enquanto tal devido à fixação de uma taxa de juros básica na economia (PARANÁ, 2016).

Segundo Marx (2017b), o capital fictício assume fundamentalmente três formas. Primeiro, títulos de dívidas privadas, chamadas de "letras de câmbio" por Marx, que se referem a direitos de renda de juros a partir de valorização futura. Segundo, ações de empresas, que constituem direitos de valorização futura, em que a ficção está presente não na abertura de capital para financiamento da atividade produtiva, mas sim na circulação e negociação dos títulos no mercado secundário. Terceiro, títulos da dívida pública, que são direitos de remuneração futura oriunda da tributação estatal e que não possuem vinculação e nem representam capital produtivo algum. "O capital, do qual o pagamento pelo Estado é considerado um fruto (juros), é [...] ilusório, fictício. A soma que foi emprestada ao Estado já não existe. Além disso, ela jamais se destinou a ser gasta, investida como capital." (MARX, 2017b, p.522) (PAULANI, 2009) (PARANÁ, 2016).

O capital fictício apresenta um caráter dialético, isto é, enquanto capital, ele é real e fictício ao mesmo tempo. Real porque, da perspectiva individual (portanto, da aparência), ele se comporta como capital pelo fato do indivíduo receber um lucro (fictício ${ }^{3}$ ) advindo das transações financeiras, fruto da mais pura especulação. Fictício porque, da perspectiva da totalidade social (portanto, da essência), não possui substância que lhe sustente uma vez que não corresponde ao valor do capital real tampouco éfruto dovalor-trabalho. Dado a impossibilidade 
de materializar completamente toda a riqueza financeira, o capital fictício só pode existir na medida que todos ou a maioria de seus possuidores não tentem convertê-lo em dinheiro ao mesmo tempo (SABADINI, 2011) (PARANÁ, 2016). Considerar essa dialética do capital fictício é levar em conta que o entendimento da dinâmica global do capital somente se faz satisfatória mediante a consideração das duas dimensões da riqueza, tanto seu aspecto de totalidade/essência quanto de individualidade/aparência, visto que essa não pode ser desconsiderada do conjunto interpretativo da dinâmica capitalista (SABADINI, 2015).

Uma crítica que frequentemente surge é a respeito da inflada ênfase que alguns marxistas concedem à esfera financeira (e, consequentemente, à circulação de capital), em detrimento da esfera de produção. Contra tal argumento, Chesnais (1996) Sabadini (2011), Paraná (2016) e Mollo (2011) afirmam que o capital fictício dispõe apenas de uma autonomia relativa em relação à esfera produtiva, porque apesar de não gerar valor, ele exige remuneração. Autonomia porque, devido à ação das flutuações especulativas, ele desfruta de certo grau de independência em relação à esfera produtiva, e relativa porque, em última instância, sua remuneração exigida advém do capital produtivo, do valor-trabalho e da extração de mais-valor. Assim sendo, sua autonomia não é absoluta, o que significa reconhecer a sua dinâmica diferenciada e a função central do capital fictício no capitalismo contemporâneo sem que se crave uma separação definitiva entre produção e circulação tampouco uma negação da centralidade do trabalho e da teoria do valor-trabalho (SABADINI, 2011).

Ainda que Carcanholo e Nakatani (2015b) reconheçam a importância da contradição entre propriedade e gestão do capital, ambos afirmam ser outra a principal contradição do atual capitalismo especulativo. A autonomia relativa supracitada desagua nessa contradição principal: a contradição produçãoapropriação de mais-valor. Tal contradição constitui o eixo explicativo da origem das crises financeiras características do capitalismo especulativo. A contradição estáno fato do capitalfictício não produzir mais-valor ao mesmo tempo que requer incessantemente a apropriação deste, que deixa de ser direcionado à ampliação e à reprodução do capital produtivo e passa a ser fonte de remuneração do capital

3 Os lucros fictícios são aqueles oriundos da valorização especulativa de ativos físicos e/ou financeiros, relacionados a uma alta/baixa na bolsa de valores, o que significa um(a) aumento/baixa nos preços das ações, isto é, um(a) crescimento/diminuição do volume de capital fictício. Para mais, ver Carcanholo e Sabadini (2015) e Sabadini (2015). 
fictício na esfera financeira ${ }^{4}$. A dialética real/fictício indica a importância dessa contradição entre produção e apropriação de mais-valor.

O Estado possui uma atuação crucial para o acirramento dessa contradição do capital fictício. Os agentes financeiros que detém títulos da dívida pública possuem o direito de remuneração futura de acordo com a taxa de juros, resultado do recolhimento estatal de impostos que, majoritariamente, são pagos pela extração de mais-valor dos(as) trabalhadores(ras) e que frequentemente não contribui com a produção de valor na esfera produtiva. Dito isso, o Estado instrumentaliza a dívida pública como um mecanismo de acumulação evalorização de capital fictício, apropriando uma parte do mais-valor e transferindo-o para a esfera financeira (SABADINI, 2011) (BARBOSA, 2016).

Para Poulantzas (1980), o Estado desempenha o papel de organização dos interesses políticos, a longo prazo, do bloco no poder. O bloco no poder consiste numa unidade contraditória entre diferentes classes e/ou frações de classe sob a hegemonia de uma dessas classes/frações, isto é, sob a capacidade desta de liderar os interesses econômicos, políticos e ideológicos das demais classes/ frações do bloco no poder (PINTO; TEIXEIRA, 2012).

Doravante, o Estado capitalista é a condensação material da relação de forças entre as classes, tanto entre as frações do bloco no poder quanto dessas para com as classes dominadas; e com a financeirização do capital, o capital fictício se estabelece como a fração hegemônica do bloco no poder do Estado, sendo responsável pelas suas diretrizes estratégicas e pelas suas transformações institucionais (POULANTZAS, 1980) (ALANO, 2007). Dito isso, Pinto e Teixeira (2012) apontam que, no Estado brasileiro, o bloco no poder está sob a hegemonia da fração bancário-financeira (bancos, seguradoras, fundos de pensão, fundos de investimento, corretoras, agências de rating, etc.) (PINTO et al, 2016).

Com isso destacado, podemos passar à análise das transformações estruturais produzidas pelo processo de financeirização do capital, graças ao apoio do Estado capitalista, que sofreu mudanças institucionais essenciais e possibilitou o impulso sem igual à ampliação e à valorização do capital fictício, com impactos significativos sobre a dívida pública, que passa a exercer um papel fundamental para o capital fictício.

${ }^{4}$ Com tal colocação não queremos insinuar que exista um capital "bom" e um capital "ruim", mas sim expor a disputa entre frações do capital que existe sobre a exploração da força de trabalho e apropriação de mais-valor. 


\section{Financeirização do capital}

Frequentemente o termo "globalização" foi ou é acionado para se referir vagamente ao processo por qual o planeta vivenciou, desde pelo menos o último quarto do séc. XX, cujas aparências projetavam/projetam uma ideia de conexão e comunicação entre as partes do mundo, sejam pessoas, sejam Estados, seja em termos econômicos, seja em termos sociais.

Para Chesnais (2001), em sua realidade fenomênica, o termo "globalização" não se referia à globalidade de fenômenos da sociedade humana, mas sim ao teor global pelo qual as ações estratégicas dos grandes grupos industriais e dos investidores institucionais ${ }^{5}$ passavam a adotar em termos de investimento e arbitragem. Em suma, por detrás da aparência, a "globalização" significava e significa a "mundialização do capital" ou "financeirização do capital" (como também é adotada na literatura). Tal fenômeno é marcado pela hipertrofia da esfera financeira, em que o capital fictício adquire uma autonomia (relativa, perante a esfera produtiva) em seu processo de valorização, de teor especulativo, e que impacta significativamente a dinâmica das empresas, a formulação de políticas pelos Estados e a vida em sociedade.

Ao contrário do que o ideal liberal lança sobre o imaginário social, a globalização não conformou um processo de integração mundial capaz de uma repartição menos desigual das riquezas. A mundialização significou, com a liberalização e desregulamentação, o fim dos constrangimentos que limitavam as tendências de polarização e desigualdade. Assim sendo, a mundialização do capital não significou o fim da existência e influência político-econômica dos Estados nacionais tampouco as relações políticas de dominação e dependência entre eles. De modo oposto, a mundialização do capital elevou a hierarquização entre os países (CHESNAIS, 2001).

Tudo se inicia na década de 60, quando a Inglaterra toma a decisão política de autorizar um mercadointerbancário paraleloe autônomoaossistemasfinanceiros nacionais, chamado de Euromercado de dólares. Para tal mercado se dirigiram os capitais estadunidenses, fugindo das regulações internas e das baixas taxas

5 "As instituições em questão compreendem os bancos, [...] as companhias de seguro, os fundos de aposentadoria por capitalização (os Fundos de Pensão) e as sociedades financeiras de investimento financeiro coletivo, administradoras altamente concentradas de ativos para a conta de cliente dispersos (os Mutual Funds) [...]." (CHESNAIS, 2001, p. 8) 
de lucro. A criação do Euromercado refletiu a queda da rentabilidade do capital produtivo e serviu de polo de atração de capital monetário ansioso por valorização (CHESNAIS, 1996). Esse mercado foi apoiado tanto pelos britânicos quanto pelos estadunidenses, que demonstravam interesse na desregulamentação dos mercados financeiros para que esses não apresentassem restrições como, por exemplo, a constituição obrigatória de reservas (em nível determinado pelo Banco Central ou legalmente estabelecido), medidas de controle sobre o câmbio e o movimento de capitais (CHESNAIS, 1996).

Já na década de 70, esse movimento foi reforçado pela quebra unilateral do sistema de Bretton Woods ${ }^{6}$ por parte dos Estados Unidos da América (EUA) ao eliminar o padrão ouro-dólar e estabelecer taxas flexíveis de câmbio. Paralelamente, os EUA estimularam a desregulamentação e a liberação dos mercados financeiros porque isso possibilitaria a manutenção de uma autonomia na política estadunidense, que sofria com déficits internos e externos, estimulando que investidores privados e governos financiassem tal déficit. Do ponto de vista dos interesses dos EUA, tais déficits tornavam insustentável a paridade e a conversão de dólar em ouro (CHESNAIS, 1996). Além disso, a desregulamentação era vantajosa para os EUA porque poderiam tirar vantagem de sua dominância nos mercados financeiros internacionais e da importância global do dólar, capazes de proporcionar segurança e liquidez, junto a altas taxas de juros (HELLEINER, 1994).

Esse cenário já apresentava as características que os Estados adotariam no processo de financeirização do capital: tomando o caso dos EUA, diante das turbulências financeiras manifestadas nas décadas de 60 e 70, a política fiscal concentrou esforços em tornar o Banco Central como emprestador de última instância para evitar a insolvência de instituições financeiras. Junto a isso, com as inovações financeiras, instrumentos de controle de liquidez foram reduzidos, ao passo que se transitou para o open market (endividamento por títulos públicos). Essas operações de mercados que o Banco Central passou a se valer para influenciar a liquidez e a taxa de juros consolidou a orientação de mercado, em

\footnotetext{
${ }^{6}$ O sistema conferia ao dólar um papel central, em que o atrelava ao ouro por uma taxa de conversão fixa, negociada internacionalmente. Por sua vez, as taxas de câmbio das demais moedas eram determinadas tendo o dólar como referência. Essas taxas eram fixas, sendo alteradas pelos Estados de acordo com as valorizações ou desvalorizações. Com seu fim, as moedas se tornaram ativos financeiros, negociáveis nos mercados de câmbio e de derivativos, significando uma considerável instabilidade para o sistema monetário internacional (CHESNAIS, 1996).
} 
que o orçamento público é submetido às expectativas privadas. Nesse sentido, a financeirização das funções públicas do Banco Central impôs a alimentação financeira do déficit público, restringindo o gasto governamental na perspectiva de estimular a demanda agregada nacional (BRAGA, 1997).

Doravante, num movimento policêntrico, houve um processo de transnacionalização dos capitais estadunidenses, fato que forçou a decisão política de retomar o controle financeiro internacional, por parte dos EUA, por meio da diplomacia do dólar.

A diplomacia do dólar se iniciou na política de Paul Vocker, então chefe do Federal Reserve (FED), em aumentar abruptamente a taxa de juros, em 1979, provocando uma violenta valorização do dólar. A partir desse momento, o FED praticou a diplomacia do dólar por meio da flutuação da taxa de juros de acordo com os interesses econômicos dos EUA em restaurar e se manter em posição dominante. Esse fenômeno não pode ser explicado pelas expectativas e incertezas dos mercados financeiros, mas sim, em última instância, pela decisão política do FED em controlar os juros e o câmbio. Com isso, reforçou-se a posição financeira dominante do dólar, tendo em vista a liquidez, a segurança e o papel de moeda internacional desempenhado por ele (TAVARES; MELIN, 1997).

Como resultado do funcionamento cotidiano da mundialização do capital, passa a existir uma imbricação significativa entre a esfera produtiva e a esfera financeira. Nessa relação, graças à desintermediação bancária, os grupos industriais conseguiram colocar diretamente seus títulos nos mercados financeiros internacionais, num processo em que as operações puramente financeiras ganharam peso cada vez mais significativo (CHESNAIS, 1996).

O desenrolar desse processo de financeirização do capital estabeleceu um regime de acumulação de dominância financeira em que, a partir dessa fase histórica do capitalismo, a valorização do capital fictício dita a lógica de acumulação e reprodução ampliada do capital a nível mundial e em que os mercados financeiros dotam de uma grande influência política sobre a determinação das grandezas macroeconômicas. ○ "poder das finanças", isto é, a força econômica e política adquirida pelas instituições financeiras, é originada pelo endividamento estatal, a partir das taxas de juros superiores à inflação e ao crescimento do PIB (CHESNAIS, 2001), demonstrando o grau de vinculação entre o Estado e o capital fictício, que consolida a hegemonia da fração bancário-financeira dentro do bloco no poder (PINTO; TEIXEIRA, 2012). 


\section{América Latina e a financeirização}

Na América Latina, o endividamento externo foi um elemento impulsionador de crescimento econômico ao longo das décadas de 60 e 70, períodos marcados por grande disponibilidade de liquidez internacional. No Brasil, a dívida externa (pública e privada) aumentou 37,5\% entre 1964 e 1969 (MOLLO, 1977). Com a elevação dos preços do petróleo em 1973, a reciclagem dos petrodólares ${ }^{7}$ possibilitou aumentar ainda mais a liquidez internacional e serviu de injeção de capitais na forma de aumento da dívida externa para os países latino-americanos. No entanto, esse cenário se tornou catastrófico após a elevação abrupta da taxa de juros por parte do FED, capitaneada pela diplomacia do dólar, afetando as taxas de juros internacionais e comprometendo a América Latina endividada (BATISTA, 1994).

Em síntese, a diplomacia do dólar e seu aumento dos juros provocou o aumento da dívida pública externa e a deterioração das bases fiscais dos Estados latinoamericanos, que, junto à liberalização dos mercados financeiros, foram forçados a aplicar ajustes fiscais para compensar a perda da capacidade tributária, por meio de corte de gastos e de privatizações. Nesse sentido, a América Latina foi vítima de uma inserção subordinada no processo de financeirização do capital, sofrendo perdas de competitividade, desindustrialização, pauperização social e crescente dependência de fluxos de capitais externos (TAVARES; MELIN, 1997).

Dessa forma, as consequências para os países latino-americanos, em geral, e para o Brasil, em particular, foram alarmantes. Diante da impossibilidade do aumento da arrecadação tributária numa conjuntura recessiva, "o governo [...] foi buscar recursos por processos inflacionários, diretamente pela emissão de moeda ou indiretamente por endividamento interno a curto prazo e taxas de juros altas. " (BATISTA, 1994, p. 16)

Outra alternativa de capitação de recursos foram os empréstimos junto ao Fundo Monetário Internacional (FMI), que marcou o retorno brasileiro ao sistema financeiro internacional. Entretanto, para recorrer a tais empréstimos, os países periféricos foram forçados a adotar as medidas propostas pelo "Consenso de Washington", denominação informal dada à coordenação de

7 O aumento dos preços do petróleo fez com que os países exportadores de petróleo adquirissem recursos que foram depositados em bancos europeus e estadunidenses e, consequentemente, servidos de empréstimos aos países da América Latina (PEDRAS, 2009). 
ações entre organismos financeiros internacionais (FMI, Banco Mundial, Banco Interamericano de Desenvolvimento) e o governo estadunidense, em 1989, a respeito das reformas econômicas implementadas na América Latina (BATISTA, 1994). Além disso, a renegociação da própria dívida externa dos países latinoamericanos foi instrumentalizada pelos organismos financeiros internacionais como forma de pressão política para a adoção de reformas estatais estruturais compatíveis com a nova ordem neoliberal. Foi dessa forma que os países da América Latina se inseriram nesse novo regime de acumulação financeira, característico do capitalismo neoliberal (GOMES, 2007).

Assim, comas reformas neoliberais, a consolidação do capital fictício se afirmava, necessitando da América Latina e do apoio de seus Estados para a criação de condições propícias ao estabelecimento desses países como plataformas de valorização financeira, principalmente pelo papel que a dívida pública interna desempenharia (TAVARES; MELIN, 1997) (PAULANI, 2009).

\section{Brasil e a dívida pública}

No Brasil, o choque de juros foi responsável pela duplicação das despesas externas com juros entre 1979 e 1981 e fez com que as exportações fossem a fonte exclusiva de amortização e de remessa dos serviços da dívida. Devido à crise da dívida externa, os mecanismos macroeconômicos que historicamente responderam por um alto dinamismo da economia brasileira foram consideravelmente afetados: mediante uma significativa desvalorização cambial em 1983, a contração das importações e a expansão das exportações (resultado do câmbio favorável e dos investimentos passados) foram a resposta à pressão de servir a dívida. Assim, o crescimento das exportações foi inteiramente absorvido pelas despesas de juros. Já na década de 90, quando a economia brasileira recorreu ao sistema financeiro internacional, a indústria e sua competitividade externa já estavam defasadas em relação ao resto do mundo (MEDEIROS; SERRANO, 2001).

O Brasil foi um dos últimos países na América Latina a solidificar o neoliberalismo. $O$ projeto neoliberal no Brasil foi resultado de um processo

${ }^{8}$ De acordo com Batista (1994), o Consenso de Washington abarcou 10 áreas: "1. Disciplina fiscal; 2. Priorização dos gastos públicos; 3. Reforma tributária; 4. Liberalização financeira; 5. Regime cambial; 6. Liberalização comercial; 7. Investimento direto estrangeiro; 8. Privatização; 9. Desregulação; e 10. Propriedade intelectual. " (P.18) 
gradual de implementação que percorreu a década de 80 e 90, e não em uma ruptura brusca, como foi o caso de Chile e Argentina pelas mãos das ditaduras empresarial-militares.

Filgueiras (2005) elabora uma importante análise da luta de classes no Brasil a respeito desse processo. É interessante destacar que a implantação do modelo neoliberal no Brasil foi consequência de disputas internas do bloco de poder, ou seja, os interesses e consequências de tal projeto instigaram contradições e atritos nas frações da classe capitalista. Isso porque o modelo de substituição de importações foi defendido por setores do empresariado ao longo da década de 80. Tal modelo se sustentava por meio do endividamento externo, amplamente acessível desde a década de 60. Somente após a crise da dívida externa e da fragilização financeira do Estado, o padrão de financiamento do modelo de substituição de importações foi quebrado e, com isso, desenrolou-se sua crise. Ademais, os programas de estabilização e de combate à inflação, apresentados ao longo da década de 80, foram insuficientes para lidar com o problema, criando então o ambiente de descrença, estagnação econômica e hiperinflação que permitiu o impulso das ideias neoliberais no Brasil.

Esse ambiente também foi possibilitado através da intensa campanha por parte da ortodoxia econômica em responsabilizar unicamente a "crise fiscal" à intervenção e ao tamanho do Estado e sua suposta inerente ineficiência na alocação produtiva. Segundo Gomes (2007), a crise fiscal significou a construção de uma justificativa ideológica para a reestruturação neoliberal do Estado.

No Brasil, se as ideias neoliberais se apresentavam de forma insipiente nas propostas de Fernando Collor e já obtinham aceitação crescente no interior do bloco no poder, foi com Fernando Henrique Cardoso (FHC), em 1994, que o projeto neoliberal se consolidou e contou com apoio total das diversas frações da classe capitalista (FILGUEIRAS, 2005). O Plano Real teve dois objetivos principais: a estabilização monetária sustentada pela valorização cambial e altas taxas de juros, e a sustentabilidade da remuneração da dívida pública interna; além da desregulamentação e abertura financeiras, privatização e desregulação do mercado de trabalho. Segundo Nakatani (2006), o Plano Real foi responsável pela imposição da lógica de valorização especulativa e de uma política econômica voltada ao capital fictício, um reflexo da sua posição de fração hegemônica no bloco no poder.

Assim sendo, o país sofreu com o aumento da vulnerabilidade externa (baixa capacidade de resistência a choques externos) e a fragilização financeira (forte 
dependência de capitais externos para financiar as contas correntes) do setor público, expressa no aumento progressivo da dívida pública (de R \$153 bilhões em 1994, para R\$ 388 bilhões em 1998) (FILGUEIRAS, 2005) (CARCANHOLO, 2005).

Na década de 90, a crise da dívida externa concedeu espaço ao endividamento interno. O aumento da dívida pública interna foi resultado do processo de abertura econômica (comercial e financeira) que captou fluxos de capitais estrangeiros, atraídos pelas altas taxas de juros e pelo processo de privatização. Isso provocou desequilíbrios nas contas externas do país e que, diante da elevada oferta de divisas estrangeiras, exigia maiores volumes de moeda nacional. $\bigcirc$ Estado brasileiro lançou títulos da dívida pública nos mercados privados para esterilizar a expansão da base monetária, fazendo a dívida pública interna aumentar significativamente. Entre 1994 e 2005, a dívida pública interna cresceu aproximadamente 50\% (GOMES, 2007).

Doravante, com o câmbio flutuante?, a sustentabilidade do Plano Real passou a depender das metas de inflação, em termos monetários, e da obtenção de elevadas taxas de superávit primário ${ }^{10}$, em termos fiscais (FILGUEIRAS, 2005), no que é comumente chamado de tripé macroeconômico. A partir da década de 90, ao exercer o papel central de sustentação do processo de abertura econômica, a dívida pública interna cresce enormemente, possibilitando com que o capital fictício usufruísse de um espaço fértil para valorização, sendo amparado pelas políticas econômicas do Estado brasileiro. Outra política econômica que consistiu no principal fator responsável pelo crescimento da dívida pública interna foi a política de juros altos, um reflexo claro da subordinação da política macroeconômica aos interesses do bloco no poder sob a hegemonia da fração bancário-financeira (NAKATANI, 2006) (GOMES, 2007).

Nesse sentido, Gomes (2007) aponta que

O orçamento público, portanto, tornou-se uma peça fundamental de

9 Diante da crise no balanço de pagamentos em 1999, a especulação contra o Real e a grande perda de reservas fez com que o Banco Central do Brasil abandonasse a política de bandas cambiais, que consistiu no principal ponto da política de combate à inflação do Plano Real, e implantasse o regime de metas de inflação. (BASTOS; RODRIGUES; LARA; 2015).

${ }^{10}$ Depois da crise de 1999, os acordos entre Brasil e FMI firmavam o compromisso de o primeiro alcançar metas de superávit primários, visando reduzir a relação dívida pública/PIB e que, consequentemente, reduziram a capacidade do Estado de promover políticas públicas. 
ajustamento da economia brasileira aos desequilíbrios causados pelos fluxos de liquidez internacional [oriundos da abertura econômica]. As finanças públicas e sua relação com os mercados financeiros se concretizaram. As políticas fiscal, monetária e cambial são então conduzidas com o objetivo de manter a estabilidade e a tranquilidade para os negócios financeiros (p. 199).

O crescimento em quantidade e em importância da dívida pública tem implicado no direcionamento da gestão e das políticas econômicas aos interesses do capital fictício. A segurança dos credores depende, em geral, da aplicação de políticas de austeridade fiscal capazes de gerar superávits primários necessários para o pagamento dos juros da dívida pública (BARBOSA, 2016). O atendimento às necessidades da reprodução ampliada do capital por meio do crescimento da dívida pública, no seio do atual padrão de acumulação/valorização financeira, gera efeitos sobre a configuração fiscal do Estado, que cada vez mais se importa com os gastos financeiros (remuneração e amortização da dívida pública) em detrimento dos gastos correntes (planos de desenvolvimento nacional, políticas sociais). Dessa forma, a política do superávit primário desempenha o papel de criar um fundo imprescindível de remuneração do capital fictício (BARBOSA, 2016). Na perspectiva dos credores, o investimento em títulos da dívida pública se torna mais interessante porque resultam em rentabilidades econômicas mais atraentes e seguras do que os investimentos em atividades produtivas (GOMES, 2007).

Portanto, sob a fase neoliberal e a financeirização do capital, o processo de reestruturação do Estado demonstrou um caráter dialético. Por um lado, visou diminuir a participação estatal nos setores produtivos para o aumento da exploração do grande capital. Por outro, visou aumentar as responsabilidades e atribuições estatais para com o setor financeiro, principalmente pela capacidade de especulação por parte das instituições financeiras com moedas fiduciárias e, sobretudo, títulos da dívida pública; junto com o compromisso de manter políticas macroeconômicas e taxas de superávit primário agradáveis ao mercado financeiro e aos credores da dívida pública. Em relação a esse último quesito, o Estado se torna o sustentáculo do processo de acumulação do capital fictício, assumindo o compromisso de prestamista de última instância para garantir a estabilidade dos mercados financeiros (BARBOSA, 2016).

Sob a dominância do capital fictício, as funções do Estado se resumem à adoção de políticas, sejam fiscais, monetárias ou públicas, que atendam (ou, ao 
menos, não atentem contra) os interesses de valorização especulativa do capital fictício. A adoção de políticas que descontentem esses interesses é respondida com a alteração do "humor" dos mercados financeiros, impactando no fluxo de capitais e na economia periférica brasileira como um todo. Dado esse cenário, a sustentação da dívida pública é fundamental, tendo em vista a sua capacidade de assegurar a rentabilidade exigida pelo capital fictício e a saúde dos mercados financeiros.

Nesse sentido, podemos afirmar que o capital fictício - a fração bancáriofinanceira - se impôs como a fração hegemônica dentro do bloco no poder por meio da consolidação do regime de política macroeconômica (tripé macroeconômico), advinda do Plano Real, e da independência operacional conquistada pelo Banco Central do Brasil, um dos principais centros de poder do Estado brasileiro (MINELLA, 2007). Esse processo é reflexo do poder político da fração bancário-financeira e sua adesão à nova síntese neoclássica ${ }^{11}$ (PINTO; TEIXEIRA, 2012) (POULANTZAS, 1980).

\section{Governos do Partido dos Trabalhadores e o golpe institucional de 2016}

Essa configuração de política macroeconômica foi iniciada no segundo mandato de FHC e foi mantida pelos governos de Lula da Silva e Dilma Rousseff. Por mais que o Partido dos Trabalhadores (PT) tenha sido um feroz crítico desse modelo neoliberal ao longo da década de 90 e suas respectivas disputas eleitorais, o PT perpetuou tal modelo com consistência. $O$ indicativo de tal concordância já se mostrava presente na "Carta ao povo brasileiro", que Lula lançou com o objetivo de acalmar o mercado financeiro diante da temível possibilidade de não cumprimento do passivo público. Em tal escritura, Lula já apontava como viria a ser seu governo: uma aliança entre segmentos capitalistas e operários e a manutenção dos interesses do capital fictício, mas com o esforço de impulsionar o capital produtivo, principalmente com uma política comercial externa forte.

Usufruindo de uma conjuntura internacional favorável, os governos Lula foram

${ }^{11}$ A nova síntese neoclássica defende que as políticas econômicas devam "ser direcionadas à estabilidade de preços, uma vez que o crescimento seria originário do estabelecimento de norma e organizações que garantissem o direito de propriedade, à redução dos custos de transação e à melhora nas expectativas dos agentes, potencializando, assim, o funcionamento completo dos mercados. " (PINTO; TEIXEIRA, 2012, p. 922). 
capazes de aumentar consideravelmente a taxa de exportações, beneficiandose da elevação dos preços das commodities e pela redução dos preços das manufaturas possibilitadas pela ascensão da economia chinesa. Esse cenário viabilizou uma grande acumulação de reservas internacionais e o alcance de grandes taxas de superávit primário em relação ao PIB, atendendo aos interesses do mercado financeiro e dos credores da dívida pública. Tal missão foi tão bem realizada que alguns autores afirmam que a política de superávit primário se tornou mais um dogma do que uma política macroeconômica racional, partindo da perspectiva de se manter uma relação dívida pública/PIB estável (BASTOS; RODRIGUES; LARA, 2015). A manutenção do regime de política macroeconômica, iniciada no governo FHC, pelo governo Lula evidencia a hegemonia da fração bancário-financeira, cujos poderes políticos e econômicos podem ser sintetizados principalmente pelo nível da taxa de juros Selic (PINTO, TEIXEIRA, 2012) (ALANO, 2007).

Diante da crise financeira de 2008, ao que tange à esfera produtiva, o governo foi capaz de contorná-la com gastos em investimento, atuando de maneira anticíclica, por parte da demanda, e reduzindo impostos sobre produtos industrializados e operações financeiras, por parte da oferta, ensaiando uma flexibilização do regime de política macroeconômica. Ao que tange à esfera financeira, nosso lócus de interesse nesse trabalho, Helder Gomes e Paulo Nakatani (2015) apontam que houve um crescimento contínuo da dívida pública interna de 35 países entre 2005 e 2011, com uma clara aceleração após a crise de 2008. Para o Brasil, o montante de títulos da dívida pública interna passa de $\$ 545,8$ bilhões de dólares em 2007 para $\$ 803,7$ bilhões em 2008. Isso demonstra que a dívida pública é importantíssima para a reprodução do capital fictício por funcionar como regulação do sistema geral de crédito e como âncora salvaguarda em momentos de crise, tendo em vista sua segurança e seus rendimentos estáveis (BARBOSA, 2016) (CHESNAIS, 2001).

Os efeitos econômicos e ideológicos da crise internacional, o fortalecimento de outras frações de classe (segmentos exportadores e parte da indústria nacional) e, sobretudo, a flexibilização do regime de política macroeconômica definida por uma política fiscal menos ortodoxa (programas de transferência de renda, política de aumento do salário mínimo, políticas creditícias expansionistas, política anticíclica diante a crise de 2008 e uma redução da taxa Selic em 2009) apontaram para fissuras na hegemonia do capital fictício no bloco no poder, no segundo governo Lula (PINTO; TEIXEIRA, 2012). 
Sob o governo Dilma Rousseff, a fissura da hegemonia da fração bancáriofinanceiro no bloco no poder é acentuada com a redução da taxa de juros Selic e o ataque aos elevados spreads dos bancos privados brasileiros por meio do aumento da concorrência via redução dos juros aos clientes do Banco do Brasil e da Caixa Econômica. Tais ações fizeram parte da chamada "Nova matriz macroeconômica" que nasceu com a tarefa de recuperar a taxa de crescimento de formação bruta de capital fixo, possibilitando um aumento da participação do investimento no PIB (PAULANI, 2016).

Essa política se provou um insucesso devido à inação do investimento privado e ao enfraquecimento do investimento público, ao aumento da inflação e ao impacto negativo da desaceleração chinesa sobre a economia brasileira, com redução dos preços das commodities. Essa empreitada resultou em reduções nas taxas de rentabilidade dos segmentos dominantes, com exceção da fração bancário-financeira que conseguiu melhores lucros em decorrência do recuo governamental no eixo principal da "Nova matriz macroeconômica" - a taxa de juros Selic, que entre 2013 e 2015, quase dobrou, atingindo 14,25\% (PAULANI, 2016) (PINTO et al, 2016).

Esse aumento dos juros foi um dos pilares do choque recessivo que caracterizou a condução da política econômica no segundo governo Rousseff. Para Pedro Rossi e Guilherme Mello (2017), a partir de 2015, foi adotado o choque recessivo em que o governo recorreu a políticas de austeridade econômica. Tal "tratamento de choque" envolveu um choque fiscal (queda de 2,9\% do PIB em termos de despesas primárias), choque de preços administrados (aumentos em energia e gasolina, com impactos na inflação), choque cambial (desvalorização cambial em mais de 50\% em relação ao dólar) e o já mencionado choque monetário (elevação da taxa de juros). Rousseff seguiu com o receituário neoliberal de austeridade transformando desaceleração em recessão econômica, contribuindo para o que veio a se tornar a maior crise econômica da história do país, devido à opção política pelo choque recessivo. Haviam alternativas tanto em relação à intensidade quanto à direção das medidas implementadas.

Tais ações promoveram um aumento significativo na dívida pública interna. De dezembro de 2014 até dezembro de 2015, a dívida pública interna aumentou de 46,12\% em relação ao PIB para 54,81\%. Isso é explicado pelo déficit primário que forçou com o governo recorresse à emissão de títulos e pelo reajuste dos índices de juros, câmbio e inflação, que subiram como resultado do choque recessivo (BORGES, 2017). 
Por mais que tenha seguido as orientações mercadológicas e tenha aplicado a austeridade econômica, o movimento pelo impeachment de Dilma Rousseff ganhou corpo com o desenrolar da recessão econômica. A adoção de medidas voltadas para a recuperação da confiança dos mercados demonstrou a procura do governo Rousseff em estabelecer um novo "acordo" com o bloco no poder; no entanto, tal tentativa aparentou não surtir mais efeito. A política conciliatória do Partido do Trabalhadores foi vazia de eficácia por conta das condições históricas que inviabilizavam o "acordo" de outrora: "cenário externo desfavorável, Operação Lava Jato, extrema desconfiança das elites com o PT, dificuldade em mobilizar a base do PT em prol do ajuste fiscal, etc." (PINTO et al, 2016, p.23). Um alinhamento de frações de classe se impôs: a mídia corporativa, o poder Legislativo, o poder Judiciário, as grandes entidades patronais e o mercado financeiro se uniram no processo de derrubada da presidente petista.

Para fundamentar legalmente o processo de impedimento, foi criado um malabarismo jurídico no intuito de imputar crime de responsabilidade por suposta violação da lei orçamentária mediante o cometimento das "pedaladas fiscais" (apelido concedido aos atrasos do Tesouro de repasses para bancos públicos encarregados de executar políticas econômicas e sociais, ato que possibilitava uma maquiagem contábil) por parte de Rousseff. Como é de praxe nos ordenamentos jurídicos burgueses, o aparato jurídico manobra a legalidade de acordo com seus interesses políticose, em momentos de crise, isso se manifesta de maneira mais aguda. Na realidade, a condenação resultada do processo de impedimento de Rousseff é calcada mais numa interpretação política do que em tecnicidades e argumentos jurídicos-formais, visto a não há passividade jurídica a respeito do tema.

A peça jurídica que oferece a denúncia contra a Presidenta Ihe imputa crime de responsabilidade por violar a lei orçamentária mediante dois pontos. Primeiro, a realização de "pedaladas fiscais" em que a denúncia afirma ter ocorrido uma operação de crédito, ação vedada pela Lei de Responsabilidade Fiscal (LRF). Segundo, a promulgação de decretos de abertura de créditos suplementares. Sobre o primeiro ponto, a LRF não aponta o que seja uma operação de crédito, sendo que os conceitos utilizados secularmente são iguais e oriundos do Direito Privado, não se podendo recorrer à condenação por equivalência, isto é, um "como se fosse", por violar o princípio da taxatividade, ou seja, crime é aquilo literalmente posto em lei (TARDELLI, 2017). Além disso, o laudo técnico do Senado Federal demonstra que não houve participação direta da Presidenta, portanto, não é 
possível vincular dolo de Rousseff à realização das "pedaladas". Ao que tange à questão dos créditos suplementares, o mesmo laudo aponta que três decretos autorizaram despesas novas que seriam incompatíveis com a meta fiscal da época. Antes disso, é verdadeiro que a emissão desses decretos não incorreu à prévia autorização legislativa. No entanto, esse tipo de prática foi e é recorrentemente acionado por administrações anteriores e Estados da federação, sempre com jurisprudência do Tribunal de Contas da União (TCU), que apenas mudou seu entendimento a respeito da prática em outubro de 2015, ou seja, após a emissão dos decretos. $O$ entendimento anterior do TCU referendava a possibilidade de abrir crédito suplementar quando o relatório bimestral de desempenho fiscal indicasse descumprimento da meta de superávit (como foi o caso), uma vez que a apuração definitiva do resultado fiscal é somente anual. Ademais, a meta fiscal foi ampliada por lei aprovada pelo Congresso Nacional, validando os decretos assinados por Rousseff. Ou seja, o Congresso Nacional que acusou Rousseff de descumprimento da lei orçamentária é o mesmo que adequou e alterou a meta fiscal para o ano de 2015, após negociações entre governo e Congresso Nacional, não havendo, portanto, crime de responsabilidade que justifique o impedimento de Dilma Rousseff.

Tal fato nos permite afirmar que tenha ocorrido um golpe dentro dos marcos institucionais no Brasil, ao estilo dos "golpes brandos" que vêm marcando a história da América Latina (como Venezuela, Bolívia, Honduras e Paraguai) (BORÓN, 2015).

\section{A ofensiva neoliberal e o Novo Regime Fiscal}

Como o próprio Michel Temer já admitiu (VIEIRA, 2016), o golpe institucional foi motivado pela não adoção integral, por parte de Rousseff, do projeto "Uma ponte para o futuro", programa de medidas de corte neoliberal. Para dar andamento a tal projeto, Henrique Meirelles, representante dos interesses de Wall Street, assume o Ministério da Fazenda. Sob doses cavalares de influência midiática, o discurso sobre o desequilíbrio das contas públicas como causa da crise econômica ganha bastante respaldo social. Sob o governo Temer, os interesses do capital fictício são priorizados em detrimento das necessidades da economia real, sobretudo, a renda e o emprego, tendo em vista a forte campanha política por atração de investidores financeiros (BORGES, 2017).

Aproveitando esse cenário e em consonância orgânica com o Fundo Monetário 
Internacional (IMF, 2016), Meirelles advoga pela aprovação do Novo Regime Fiscal (NRF). O NRF consiste numa medida constitucional que promove o congelamento real dos gastos públicos do Estado ao longo de 20 anos, sendo apenas atualizados anualmente pelo índice de inflação do ano anterior.

Segundo o governo, tal medida é voltada para atingir o equilíbrio das contas públicas e retirar o Brasil da crise econômica. $\bigcirc$ discurso oficial possui fundamentos ideológicos semelhantes àqueles criados durante a crise da dívida externa, como descrito por Gomes (2006). A culpa do péssimo cenário é atribuída unicamente ao Estado, recorrendo a um suposto alarmante descontrole fiscal dos gastos estatais, especialmente por conta de uma presumida imoderação da gestão petista, desconsiderando os condicionantes externos e covenientemente ausentando outros elementos dessa análise. No entanto, questionamentos são levantados sobre a possibilidade de uma medida de tão longo prazo - 20 anos ter impacto imediato na economia brasileira.

Na realidade, o NRF consiste num mecanismo institucional que visa promover a alteração da atuação do Estado na economia. Por meio da asfixia orçamentária, o NRF força a retração da participação do Estado enquanto indutor de investimento, crescimento e desenvolvimento econômicos; pavimentando um caminho para a desarticulação dos serviços públicos, que aguardarão seu gradual sucateamento para que o processo de privatização se torne "inevitável". Dessa forma, os capitais ganharão espaços para expansão e acumulação. Em outras palavras, o Estado tem sua atuação restrita apenas à delimitação de quais gastos/ programas serão mais ou menos contidos e sua definição dada por uma variável econômica (FÓRUM 21 et al, 2016).

O NRF constitui uma política de caráter acíclico, ou seja, os gastos públicos serão limitados independentemente do ciclo econômico. Para além dos malefícios mencionados, essa característica pode ser entendida como um grande benefício para o capital fictício. O NRF se restringe a estabelecer um limite aos gastos primários do Estado, não tangenciando absolutamente nada a respeito dos gastos financeiros. É importante destacar que, quando o Brasil vivenciar uma ascensão econômica, toda a arrecadação estatal que superar as despesas estabelecidas, em termos reais, será direcionada ao pagamento dos juros da dívida pública. Isso significa que as melhorias provenientes do crescimento econômico não poderão ser redirecionadas e usufruídas pela sociedade brasileira, que sofrerá com o crescimento demográfico e a consequente redução dos gastos públicos per capita. 
As análises de Poulantzas (1980) em relação ao Estado capitalista contribuem para a compreensão do cenário brasileiro. Segundo ele, as funções econômicas do Estado apresentam lugar dominante em seu seio. $\bigcirc$ conjunto das operações do Estado se reorganiza em função do seu papel econômico, causando transformações institucionais que afetam o conjunto dos aparelhos do Estado, de acordo e em adaptação à estratégia política da fração hegemônica - no caso brasileiro, a fração bancário-financeira.

Dito isso, o Novo Regime Fiscal desempenha um papel fundamental na política estratégica do bloco no poder. A unidade contraditória do bloco no poder orientada pela fração bancário-financeira envolveu transformações institucionais do Estado (Novo Regime Fiscal) cujos dispositivos e centros de orientação da política do Estado (sobretudo, Ministério da Fazenda e Banco Central do Brasil) sustentam os interesses hegemônicos financeiros, com pontos de estrangulamento (a disputa distributiva do orçamento) e usufruto (atuação em áreas não cobertas pelos serviços públicos por restrição orçamentária) dos interesses das demais frações do capital (POULANTZAS, 1980).

Isso faz como que o NRF seja uma atualização considerável da política de superávit primário. Ele permite que o limite da variável de despesas primárias do cálculo do resultado primário seja constante por 20 anos, cabendo a um futuro crescimento econômico conceder o excedente a ser apropriado pelo capital fictício na forma de pagamento dos juros da dívida pública. Não sendo apenas numa atualização do superávit primário, o NRF significa a instituição de um colossal mecanismo de transferência de renda, em que o mais-valor produzido e extraído pelo Estado brasileiro, na forma de impostos, majoritariamente extraídos da força de trabalho, é apropriado pelo capital fictício, na forma dos juros da dívida pública.

Considerações finais

Portanto, pode ser visto que a conformação do processo de financeirização do capital teve participação fundamental do Estado por meio de desregulamentações, liberalizações e abertura financeiras que permitiram o enorme aumento do volume do capital fictício. Nesse processo, a América Latina esteve subjugada aos fluxos de capitais externos que influenciaram na configuração econômica e política do Estado.

Como reflexo da hegemonia da fração bancário-financeira no bloco no poder e por meio do regime de política macroeconômica - tripé macroeconômico aliado à política de juros altos, a atenção às vontades do capital fictício se tornou 
fundamental para a agenda e para o modelo institucional do Estado, que sustenta uma dívida pública como uma forma primordial de valorização de capital fictício, tanto em tempos de normalidade quanto em tempos de crise.

O tamanho da dívida pública sustentada pelo Estado com o orçamento público expõe a dimensão grandiosa da contradição entre produção e apropriação de mais-valor que o capital fictício engendra no capitalismo contemporâneo. Nesse cenário, o Novo Regime Fiscal significa a acentuação da transferência de maisvalor da classe trabalhadora brasileira - a que mais sofre com a expropriação via impostos - para o capital fictício.

\section{BIBLIOGRAFIA:}

ALANO, Jorge. Economia e política no processo de financeirização do Brasil (1980-2006). Tese (Doutorado). Pontifícia Universidade Católica de São Paulo. São Paulo, 2007.

BARBOSA, Flavia Fenix. As contradições do Estado e da dívida pública no capitalismo contemporâneo. Revista Pesquisa \& Debate. São Paulo. Vol. 27. Número 2 (50). Dez 2016.

BASTOS, C.P.; RODRIGUES, R.; LARA, F.M. As finanças públicas e o impacto fiscal entre 2003 e 2012: 10 anos de governo do Partido dos Trabalhadores. Ensaios FEE, Porto Alegre, v. 36, n. 3, p. 675-706, dez. 2015.

BATISTA, Paulo Nogueira. O Consenso de Washington: a visão neoliberal dos problemas latino-americanos. In: Barbosa Lima Sobrinho et al. Em Defesa do Interesse Nacional: Desinformação e Alienação do Patrimônio Público. São Paulo: Paz e Terra, 1994.

BORGES, Helena. Temer prefere atender a elite financeira a adotar medidas eficazes contra desemprego. The Intercept Brasil, 17 de fevereiro de 2017. Disponível em: <https://theintercept.com/2017/02/13/temer-prefere-atendera-elite-financeira-a-adotar-medidas-eficazes-contra-desemprego/>. Acesso em: 29/05/2017 
BORÓN, Atilio Alberto. Grecia, Brasil y después. In: MINISTERIO DE COMUNICÁCION. América Latina en alerta por "golpes blandos" contra gobiernos democráticos y progresistas. Bolivia, septiembre 2015.

BRAGA, José Carlos de Souza. Financeirização global - o padrão sistêmico de riqueza do capitalismo contemporâneo. In: FIORI, José Luís; TAVARES, Maria da Conceição (Org.). Poder e dinheiro: uma economia política da globalização. Petrópolis: Editora Vozes, 1997.

CARCANHOLO, Marcelo Dias. Dependência e superexploração da força de trabalho no desenvolvimento periférico. In: Seminario Internacional REG GEN: Alternativas Globalização. UNESCO, Organización de las Naciones Unidas para la Educación, la Ciencia y la Cultura, Rio de Janeiro: 2005.

CARCANHOLO, Reinaldo; NAKATANI, Paulo. O capital especulativo parasitário: uma precisão teórica sobre o capital financeiro, característico da globalização. In: GOMES, Helder (Org.). Especulação e lucros fictícios: formas parasitárias da acumulação contemporânea. São Paulo: Outras expressões, 2015a.

Capitalismo especulativo e alternativas para América Latina. In: GOMES, Helder (Org.). Especulação e lucros fictícios: formas parasitárias da acumulação contemporânea. São Paulo: Outras expressões, 2015b.

CARCANHOLO, Reinaldo; SABADINI, Maurício de S. Capital fictício e lucros fictícios. In: GOMES, Helder (Org.). Especulação e lucros fictícios: formas parasitárias da acumulação contemporânea. São Paulo: Outras expressões, 2015.

CHESNAIS, François. A mundialização do capital. São Paulo: Xamã, 1996.

Mundialização: o capital financeiro no comando. In: Revista Outubro, São Paulo, n. 5, p. 7-28, 2001.

FORÚM 21; FUNDAÇÃO FRIEDRICH EBERT STIFTUNG (FES); GT DE MACRO DA SOCIEDADE BRASILEIRA DE ECONOMIA POLÍTICA (SEP); PLATAFORMA POLÍTICA SOCIAL. Austeridade e retrocesso: finanças públicas e política fiscal no Brasil. São Paulo: setembro, 2016. 
FILGUEIRAS, Luiz. Projeto político e modelo econômico neoliberal no Brasil: implantação, evolução, estrutura e dinâmica. Versão preliminar, 2005.

FIORI, José Luís. Formação, expansão e limites do Poder Global. In: FIORE, José Luís (Org.). O poder americano. Petrópolis: Editora Vozes, 2004.

GOMES, Fábio Guedes. Acumulação de capital via dívida pública:contribuição para uma crítica à razão da crise fiscal. Tese (Doutorado). Universidade Federal da Bahia, 2007.

GOMES, Helder; NAKATANI, Paulo. A natureza e as contradições da crise capitalista. In: GOMES, Helder (Org.). Especulação e lucros fictícios: formas parasitárias da acumulação contemporânea. São Paulo: Outras expressões, 2015.

HELLEINER, Eric. States and the reemergence of global finance. Cornell University, 1994.

INTERNATIONAL MONETARY FUND. Brazil: 2016 Article IV Consultation - Press Release; Staff Report; and Statement by the Executive Director for Brazil. IMF Country Report N 16/348. D.C. Washignton: November, 2016.

MARX, Karl. O Capital: crítica da economia política. Livro I: O processo de produção do capital. $2^{a}$ ed. São Paulo: Boitempo, 2017a.

O Capital: crítica da economia política. Livro III: o processo global de produção capitalista. $1^{a}$ ed. São Paulo: Boitempo, 2017b.

MEDEIROS, Carlos; SERRANO, F.Inserção externa, exportações ecrescimento no Brasil. In: FIORI, José Luís; MEDEIROS, Carlos (Org.). Polarização mundial e crescimento. Rio de Janeiro: Vozes, 2001.

MINELLA, Ary. Representação de classe do empresariado financeiro na América Latina: a rede transassociativa no ano 2006. Revista de Sociologia e Política, Curitiba, v.28, p. 31-56, jun. 2007.

MOLLO, Maria de Lourdes Rollemberg. Capital fictício, autonomia produção- 
circulação e crises: precedentes teóricos para o entendimento da crise atual. In: Revista Economia, Brasília, v.12, n.3 p. 475-497. Set/dez 2011.

O desequilíbrio do balanço de pagamentos do Brasil 1966-1975: o papel do endividamento externo. Brasília: Editora Universidade de Brasília, 1977.

NAKATANI, Paulo. O papel e o significado da dívida pública na reprodução do capital. Primer Simposio Internacional Sobre Deuda Pública, Auditoria Popular y Alternativas de Ahorro e Inversión para los Pueblos de América Latina, Venezuela, set. 2006.

PARANÁ, Edemilson. Afinança digitalizada:capitalismo financeiro erevolução informacional. Florianópolis: Insular, 2016.

PAULANI, Leda Maria. A crise do regime de acumulação com dominância financeira e a situação no Brasil. Estudos Avançados (USP Impresso), v. 23, p. 25-39, 2009.

Capitalismo e Estado no Brasil: A saga dos investimentos públicos. In: Revista Politika. Vol. 1, n. 3. Brasília: Editora FJM, 2016

PEDRAS, Guilherme Binato Villela. Histórico da Dívida Pública: de 1964 até os dias atuais. In: Dívida pública: a experiência brasileira. Tesouro Nacional, 2009.

PINTO, Eduardo Costa et al. A economia política dos governos Dilma: acumulação, bloco no poder e crise. In: XXI Encontro Nacional de Economia Política, São Bernardo do Campo/SP, 2016.

PINTO, Eduardo Costa; TEIXEIRA, Rodrigo Alves. A economia política dos governos FHC, Lula e Dilma: dominância financeira, bloco no poder e desenvolvimento econômico. Revista Economia e Sociedade, Campinas, v.21, Número Especial, p. 909-941, dez. 2012

POULANTZAS, Nicos. O Estado, o poder, o socialismo. Rio de Janeiro: Edições Graal, 1980.

ROSSI, Pedro; MELLO, Guilherme. Choque recessivo e a maior crise da história: 
a economia brasileira em marcha ré. Centro de Estudos de Conjuntura e Política Econômica - IE/UNICAMP. Nota do Cecon, n.1, 2017.

SABADINI, Maurício de S. O capital fictício e suas formas: lucros de fundador, diferencial e fictícios. In: GOMES, Helder (Org.). Especulação e lucros fictícios: formas parasitárias da acumulação contemporânea. São Paulo: Outras expressões, 2015.

Trabalho e especulação financeira: uma relação (im)perfeita. Temporalis, Brasília (DF), ano 11, n.22, p.241-269, jul./dez. 2011.

TARDELLIE, Brenno. Análise: Dilma Rousseff foi afastada sem ter cometido crime de responsabilidade. Justificando, 31 de agosto de 2017. Disponível em: $\quad$ <http://justificando.cartacapital.com.br/2017/08/31/dilma-rousseff-foiafastada-do-cargo-sem-ter-cometido-crime-de-responsabilidade/>. Acesso em: 29/09/2017

TAVARES, Maria da Conceição; MELIN, Luiz Eduardo. Pós-escrito: a reafirmação da hegemonia norte-americana. In: FIORI, José Luís; TAVARES, Maria da Conceição (Org.). Poder e dinheiro: uma economia política da globalização. Petrópolis: Editora Vozes, 1997.

VIERIA, Inacio. Michel Temer diz que impeachment aconteceu porque Dilma rejeitou "Ponte para o Futuro". The Intercept Brasil, 22 de setembro de 2016. Disponível em: <https://theintercept.com/2016/09/22/michel-temer-diz-queimpeachment-aconteceu-porque-dilma-rejeitou-ponte-para-o-futuro/>. Acesso em: 28/05/2017 